\title{
AKSESIBILITAS PERMODALAN PERBANKAN BAGI WIRAUSAHAWAN DIFABEL DI D.I YOGYAKARTA UNTUK MEWUJUDKAN EKONOMI INKLUSI
}

\author{
Diska Arliena Hafni ${ }^{1}$; Fitri Maulidah Rahmawati ${ }^{2}$ \\ Universitas 'Aisyiyah Yogyakarta, Sleman, Daerah Istimewa Yogyakarta, Indonesia ${ }^{1,2}$ \\ diskaarliena@unisayogya.ac.id
}

\begin{abstract}
This study aims to determine the opportunities and challenges faced by diffable entrepreneurs in accessing banking capital. In addition, it is also to find out the extent to which the role of banks provides access to capital for diffable entrepreneurs. The study was a descriptive qualitative study involving blind and disabled disabled entrepreneurs who were members of Persatuan Tuna Netra Indonesia (PERTUNI) DIY, Persatuan Penyandang Disabilitas Indonesia (PPDI) DIY area and Ojek Difa DIY motorcycle taxi. Data collection uses interview, observation and documentation methods. Data analysis is done by collecting data, reducing data, presenting data (data display), and drawing conclusions. The results showed that only a small proportion of blind diffable entrepreneurs had interacted with the banking sector, the rest preferred to interact with other financial institutions such as cooperatives established by PERTUNI and BMT. They chose this because banking services were considered to be quite complicated or lacking in access for blind diffable entrepreneurs. On the other hand, disabled entrepreneurs have often interacted with banking and there are no significant problems in the process of lending bank capital. However, both the disabled and forced entrepreneurs hope there will be an increase in services for diffable entrepreneurs primarily in terms of facilities and infrastructure as well as more diffable-friendly banking service products.
\end{abstract}

Keywords: accesisbility of banking capital, diffable entrepreneurs, economic inclusion

\begin{abstract}
ABSTRAK
Penelitian ini bertujuan untuk mengetahui peluang dan tantangan yang dihadapi oleh wirausahawana difabel dalam mengakses modal perbankan. Selain itu, juga untuk mengetahui sejauh mana peran bank memberikan akses permodalan bagi wirausahawan difabel. Penelitian ini merupakan penelitian deskriptif kualitatif yang melibatkan para wirausahawan difabel yang merupakan anggota organisasi Persatuan Tuna Netra Indonesia (PERTUNI) DIY, Persatuan Penyandang Disabilitas Indonesia (PPDI) DIY dan Ojek Difa DIY. Pengumpulan data menggunakan metode wawancara, observasi dan dokumentasi. Analisis data dilakukan dengan mengumpulkan data, mereduksi data, menyajikan data (tampilan data), dan menarik kesimpulan. Hasil penelitian menunjukkan bahwa hanya sebagian kecil wirausahawan difable netra yang telah berinteraksi dengan sektor perbankan, selebihnya lebih suka berinteraksi dengan lembaga keuangan lain seperti koperasi yang didirikan oleh PERTUNI dan BMT. Mereka memilih demikian karena layanan perbankan dianggap cukup rumit atau kurang bagi wirausahawan difabel netra. Di sisi lain, wirausahawan difabel daksa sering berinteraksi dengan perbankan dan tidak ada masalah dalam proses meminjamkan modal bank. Namun, baik wirausahawan difabel netra maupun daksa berharap akan ada peningkatan layanan bagi para pengusaha
\end{abstract}


difabel terutama dalam hal sarana dan prasarana serta produk layanan perbankan yang lebih mudah diakses bagi wirausahawan difabel.

Kata kunci: aksesibilitas modal perbankan, pengusaha difabel, ekonomi inklusi

\section{PENDAHULUAN}

Data Dinas Sosial Daerah Istimewa Yogyakarta menyebutkan bahwa jumlah penyandang disabilitas di DIY mencapai 25.050 orang (Tribun Jogja. Com, 2016). Penyandang disabilitas terbanyak menurut survei tersebut adalah penyandang yang mengalami lebih dari satu jenis keterbatasan (gabungan), yaitu sebesar $39,97 \%$, kemudian diikuti dengan keterbatasan melihat, dan berjalan atau naik tangga (www.depkes.go.id). Namun demikian, pemetaan berikutnya mendapati bahwa persentase anak tunanetra pada tahun 2013 meningkat hampir dua kali lipat bila dibandingkan dengan tahun 2010 (Mujaddid, 2014). Regulasi Pemerintah terkait pemberdayaan penyandang difabel diatur dalam Undang-undang konvensi hak-hak penyandang disabilitas Nomor 19 Tahun 2011. UU Konvensi hak penyandang difabel tersebut mengakui dan mendorong lebih banyak lagi terwujudnya pekerjaan dan lapangan kerja bagi penyandang difabel dalam mendapatkan akses kerja di setiap lembaga kerja. Lebih khusus, Peraturan Daerah Istimewa Yogyakarta Nomor 4 Tahun 2012 pasal 16-40 bagian III ikut menguatkan isu tentang pemenuhan dan perlindungan hak-hak kaum difabel.

Penelitian Winasti (2012) menunjukkan bahwa motivasi berwirausaha pada penyandang disabilitas fisik adalah untuk menafkahi keluarga, menjalin hubungan dengan orang banyak, menolong penyandang disabilitas fisik agar lebih sejahtera, adanya harga diri, dan keinginan menyetarakan dengan individu normal. Faktor yang menjadi hambatan dalam bekerja berasal dari faktor eksternal yaitu factor masalah produksi dan tenaga kerja, masalah pemasaran, permodalan, desain, kualitas produk dan mitra kerja. Kedua subjek dalam menghadapi hambatan menggunakan strategi problem focused coping.

Penelitian Hafni (2017) menemukan fakta bahwa Dinas Sosial DIY telah melakukan pemberdayaan ekonomi kepada para penyandang difabel. Pemberdayaan tersebut berupa seminar, pelatihan tentang UMKM dan pemberian bantuan modal. Bantuan modal dalam bentuk hibah yang diberikan Dinsos berupa uang tunai yang jumlahnya berkisar 2-5 juta rupiah per orang. Modal tersebut digunakan sebagai modal awal bagi wirausahawan difabel yang akan memulai usahanya atau sebagai tambahan modal bagi yang sudah menjalankan usaha. Bantuan modal dari Dinsos tersebut jumlahnya sangat terbatas, sedangkan usaha yang dijalankan butuh berkembang. Sejauh ini, wirausahawan difabel belum memahami dan memiliki keterbatasan akses untuk mendapatkan bantuan modal dari lembaga keuangan.

Menurut Angraini dan Syahrir (2013), pada dasarnya hambatan dan rintangan yang dihadapi para pengusaha UMKM dalam meningkatkan kemampuan usaha sangat kompleks dan meliputi berbagai aspek yang mana salah satu dengan yang lainnya saling berkaitan. Hambatan tersebut antara lain; kurangnya permodalan baik jumlah maupun sumbernya, kurangnya kemampuan manajerial dan keterampilan beroperasi serta tidak adanya bentuk formil dari perusahaan, lemahnya organisasi dan terbatasnya pemasaran. Di samping hal-hal 
tersebut, terdapat juga persaingan yang kurang sehat dan desakan ekonomi sehingga mengakibatkan ruang lingkup usaha menjadi terbatas.

Permasalahan modal timbul karena tidak adanya titik temu UMKM sebagai debitor dan pihak kreditor. Di sisi debitor, karateristik dari sebagian besar UMKM di Indonesia antara lain adalah masih belum menjalankan bisnisnya dengan prinsipprinsip manajemen modern, tidak/belum memiliki badan usaha resmi, serta keterbatasan aset yang dimiliki. Sementara itu, di sisi kreditor, pemodal atau lembaga pembiayaan untuk melindungi resiko kredit, menuntut adanya kegiatan bisnis yang dijalankan dengan prinsip-prinsip manajemen modern, ijin usaha resmi serta adanya jaminan (collateral). Lembaga perbankan sebagai salah satu sumber modal secara optimal masih belum dapat membantu permasalahan yang dihadapi UKM.

Lebih lanjut Angraini dan Syahrir (2013) menjelaskan tentang Peranan Kredit Usaha Rakyat (KUR) Bagi Pengembangan UMKM, bahwa variabel modal sendiri dan variabel modal kredit usaha rakyat (KUR) dianggap konstan terhadap pendapatan UMKM. Semakin besar modal sendiri yang diberikan, maka menyebabkan semakin tinggi pula tingkat pendapatan yang akan didapatkan oleh UMKM, begitu juga sebaliknya. Semakin besar jumlah KUR maka semakin tinggi pula tingkat pendapatan yang akan didapatkan pengusaha UMKM, begitu juga sebaliknya. Dengan demikian, dapat diartikan bahwa pinjaman modal berpengaruh terhadap tingkat pendapatan UMKM.

Permasalahan atau hambatan yang dihadapi wirausahawan difabel sektor UMKM di atas perlu mendapatkan perhatian serius dari para pemangku kepentingan. Wirausahawan difabel perlu mendapatkan perlindungan dalam proses menjalankan bisnisnya, salah satunya tentang akses permodalan perbankan. Ekonomi inklusi merupakan suatu lingkungan bisnis yang ramah terhadap wirausahawan difabel. Hal ini dalam rangka pemenuhan hak-hak kaum difabel di bidang pemberdayaan ekonomi. Dibutuhkan komitmen yang kuat dari berbagai pihak untuk mewujudkan ekonomi inklusi. Perbankan memiliki andil dalam mewujudkan ekonomi inklusi, utamanya terkait permodalan.

Pemberdayaan Masyarakat untuk UKM hendaknya mengacu pada prinsipprinsip dasar pendampingan masyarakat, yaitu: belajar dari masyarakat, pendamping sebagai fasilitator dan dapat tercipta saling belajar dan berbagi pengalaman. Implementasi kebijakan dalam rangka strategi pemberdayaan masyarakat untuk mengembangkan UKM tidak bisa secara parsial hanya bidang ekonomi permodalan saja, namun juga harus berorientasi secara keseluruhan atas kebutuhan UKM baik secara individu maupun kelompok termasuk mendasarkan pada potensi sumberdaya manusianya (Karsidi, 2007).

Berdasarkan analisis kondisi di atas, dibutuhkan pemetaan dan penggalian informasi yang mendalam tentang bagaimana pemahaman wirausahawan difabel tentang akses permodalan perbankan. Selain itu perlu diteluri lebih jauh tentang apa saja peluang dan tantangan (hambatan) yang dihadapi wirausahawan difabel dalam mengakses modal perbankan, serta bagaimana peran perbankan dalam menyediakan akses permodalan bagi wirausahawan difabel. 


\section{STUDI PUSTAKA DAN FOKUS PENELITIAN}

Secara definisi pengertian kelainan fungsi anggota tubuh (disabilitas fisik) adalah ketidakmampuan anggota tubuh untuk melaksanakan fungsinya disebabkan oleh berkurangnya kemampuan anggota tubuh untuk melaksanakan fungsi secara normal akibat luka, penyakit, atau pertumbuhan tidak sempurna (Suroyo, dalam Effendi, 2009). Menurut Departemen Sosial dikutip oleh Mangunsong (Rostiana dan Damayanti, 2003) bahwa disabilitas fisik didefinisikan sebagai ketidaklengkapan anggota tubuh disebabkan faktor bawaan dari lahir, kecelakaan, maupun akibat penyakit yang menyebabkan terganggunya mobilitas yang bersangkutan, contohnya amputasi tangan/kaki, paraplegia, kecacatan tulang, dan cerebral palsy.

Menurut Sarinem (2010), berbagai permasalahan dihadapi oleh penyandang disabilitas fisik. Disabilitas fisik yang dialami seseorang dapat mengakibatkan gangguan kemampuan fisik untuk melakukan suatu perbuatan atau gerakan tertentu yang berhubungan dengan kegiatan hidup sehari-hari. Disabilitas fisik juga dapat mengganggu kejiwaan atau mental seseorang sehingga menjadi rendah diri atau sebaliknya terlalu berlebihan. Disabilitas fisik menimbulkan kesulitan pula khususnya ada anak umur sekolah, yang memerlukan perhatian khusus baik dari orang tua maupun guru di sekolah. Keterbatasan fisik menyebabkan tidak dimilikinya keterampilan kerja (produksi). Hal ini menyebabkan rendahnya pendapatan dan berada di bawah garis kemiskinan.

Secara sosial, disabilitas fisik mempengaruhi ketidakmampuan hubungan dalam mengambil peranan dalam kegiatan sosial atau kelompok, kecanggungan hubungan antar manusia di masyarakat, dan ketidakmampuan saling mempengaruhi dalam suatu kelompok sosial atau interaksi sosial. Keluarga yang mempunyai anak penyandang disabilitas fisik, orang tuanya ada yang merasa malu sehingga penyandang disabilitas tidak dimasukkan sekolah, tidak boleh bergaul dan bermain dengan teman sebaya, serta kurang mendapatkan kasih sayang seperti yang diharapkan oleh anak-anak pada umumnya. Akibatnya anak tidak dapat berkembang kemampuan dan kepribadiannya, yang pada gilirannya menjadi beban keluarganya secara menetap. Terkadang masyarakat yang mempunyai warga penyandang disabilitas fisik turut terganggu kehidupannya, apabila penyancang cacat belum bisa berdiri sendiri dan ada yang menggantungkan dirinya kepada orang lain. Penyandang disabilitas fisik dimungkinkan mengalami kendala dalam pergaulan seperti sulit menemukan kelompok bermain, membentuk kelompok khusus yang cenderung menutup diri, dan antar kelompok berkompetisi secara negatif (Sarinem, 2010).

Menurut Kassam (1989), Sen dan Grown (1987), dan Paul (1987) dalam Hutomo (2000), pemberdayaan adalah penguatan masyarakat untuk dapat berpartisipasi dalam proses pengambilan keputusan yang mempengaruhi masa depannya, penguatan masyarakat untuk dapat memperoleh faktor-faktor produksi, dan penguatan masyarakat untuk dapat menentukan pilihan masa depannya. Praktik pemberdayaan bidang ekonomi bagi penyandang disabilitas secara umum memiliki kemiripan dimensi pendekatan (Hutomo, 2000), seperti misalnya: (1) bantuan modal bergulir; (2) bantuan pembangunan prasarana; (3) pengembangan kelembagaan lokal; (4) penguatan dan pembangunan kemitraan usaha; dan (5) fasilitasi dari pendampingan usaha. 
Pemberdayaan ekonomi bisa dilakukan melalui intrapreneurship dan entrepreneurship. Pemberdayaan melalui intrepreneurship adalah bagaimana mempersiapkan tenaga kerja penyandang disabilitas agar dapat diterima di pasar tenaga kerja. Pemberdayaan melalui entrepreneurship adalah pendidikan bagaimana penyandang disabilitas mampu untuk mendirikan usaha mandiri. Surwanti (2014) menyatakan bahwa penanggung jawab pelaksana pemberdayaan ekonomi penyandang disabilitas memang masih menekankan pada peran Kementrian Sosial. Penanganan inter departemental dan inter institusi sudah dilakukan, namun peran swasta belum berjalan dengan baik. Peran swasta, $N G O$, DPO juga menunjukkkan peran yang sangat penting. Implementasi pemberdayaan ekonomi bagi penyandang disabilitas mendasarkan pada peraturan perundangundangan dan kebijkan yang telah ada baik di tingkat internasional, regional, nasional dan daerah. Implementasi pemberdayaan kepada penyandang disabilitas di Indonesia masih banyak menjumpai persoalan yang memerlukan pembenahan diberbagai sisi.

Penelitian ini menggunakan teori modal sosial yang merupakan segala sesuatu yang membuat masyarakat untuk melakukan kerjasama dalam suatu jaringan untuk membangun sebuah hubungan guna mencapai tujuan bersama berdasarkan kepercayaan, resiprositas, nilai-nilai, norma-norma bersama yang mengikat anggota kelompok untuk membuat kemungkinan aksi bersama, dapat dilakukan secara efisien dan efektif (Hasbullah, 2006). Penelitihan ini juga mengunakan pendekatan sosiologi ekonomi sebagai studi tentang bagaimana cara orang atau masyarakat dalam memenuhi kebutuhan hidup mereka terhadap jasa dan barang langka, dengan cara melakukan aktifitas yang berkaitan dengan produksi, distribusi, pertukaran, dan konsumsi jasa-jasa dan barang-barang langka (Damsar, 2006).

\section{METODE PENELITIAN}

Penelitian ini merupakan jenis penelitian deskriptif kualitatif. Metode deskriptif dapat diartikan sebagai prosedur pemecahan masalah yang diselidiki dengan menggambarkan keadaan objek penelitian (seorang, lembaga, masyarakat) pada saat sekarang berdasar fakta-fakta yang tampak atau sebagaimana adanya. Denzin dan Lincoln (2002) menjelaskan tentang penelitian kualitatif seperti berikut ini, "Qualitative research is many thing to many people. Qualitative research, as a set of interpretive practice, privilages no single methodology over any others. As a site of discussion, or discourse, qualitative research is difficult to difine clearly".

Menyitir pendapat Sugiono (2007) bahwa penelitian kualitiatif merupakan penelitian yang dilakukan pada kondisi objek alamiah, di mana peneliti menjadi instrumen kunci, teknik pengumpulan data secara trianggulasi, analisa data bersifat induktif, serta hasil penelitian lebih menekankan makna daripada generalisasi. Konsekuensi penggunaan jenis penelitian ini disebut oleh Sukoharsono (2006) sebagai "a strong commitment to study a problem, demands time and resourse."

Berdasarkan uraian di atas maka orientasi teoritis yang dipakai dalam penelitian ini adalah pendekatan fenomenologis yang menekankan pada aspek subjektif dari perilaku orang atau berusaha memahami arti peristiwa atau sesuatu 
yang sedang diteliti dari kerangka berfikir dan bertindak dari orang-orang itu sendiri. Moleong (2002) menyatakan bahwa, peneliti dalam pandangan fenomeologis berusaha memahami arti peristiwa dan kaitan-kaitannya terhadap orang-orang biasa dalam situasi tertentu.

Penelitian ini ditujukan untuk mendeskripsikan dan menganalisis fenomena, peristiwa, aktivitas sosial, sikap, kepercayaan, persepsi, pemikiran orang secara individual maupun kelompok. Di samping itu, data yang ada dinyatakan dalam keadaan sewajarnya dengan tidak mengubah dalam bentuk simbol ataupun bilangan. Fenomena yang diteliti adalah keterjakauan akses (aksesibilitas) permodalan perbankan bagi wirausahawan difabel.

Pengumpulan data dalam penelitian ini menggunakan metode wawancara, observasi dan dokumentasi. Analisis data yang diperoleh dari wawancara dan dokumentasi dianalisis menggunakan deskriptif analitik. Analisis induktif ini merupakan pemikiran yang berangkat dari fakta-fakta yang khusus kemudian dari fakta itu ditarik kesimpulan. Dalam hal ini, analisis induktif adalah menginterpretasikan data hasil dokumentasi, wawancara, serta observasi yang dilakukan dalam penelitian. Analisis data kualitatif dilakukan dengan cara menguraikan, menafsirkan, dan menggambarkan data yang terkumpul secara sistematis. Analisis data dilakukan dengan model Miles dan Huberman (1992), yaitu dimulai dengan pengumpulan data, reduksi data, penyajian data (data display), dan penarikan kesimpulan.

\section{HASIL DAN PEMBAHASAN}

Penelitian ini dilaksanakan di tiga organisasi para penyandang difabel. Pertama yaitu Persatuan Tuna Netra Indonesia (PERTUNI) wilayah DIY. Kedua, dilakukan di Persaruan Penyandang Disabilitas Indonesia (PPDI) wilayah DIY). Ketiga, di Ojek Difa yaitu organisasi yang menaungi para tuna daksa untuk berprofesi sebagai tukang ojek. Total informan yang berhasil dikumpulkan dari ke tiga organisasi tersebut adalah sebanyak 12 orang. Informan berusia kisaran 40-60 tahun. Jenis usaha yang dijalankan oleh wirausahawan difabel netra sebagian besar adalah bergerak di bidang jasa pijat. Beberapa wirausahawan difabel netra berprofesi sebagai pedagang. Sedangkan untuk wirausahawan difabel daksa yang tergabung di Ojek Difa semuanya berprofesi sebagai tukang ojek dan ada juga beberapa yang berdagang. Rata-rata wirausahawan difabel menjalankan usahanya selama 3-20 tahun.

Alasan mendasar yang melatarbelakangi para penyandang difabel ini untuk menjalankan usaha adalah kemandirian ekonomi karena stigma yang berkembang di masyarakat penyandang difabel tidak dapat hidup mandiri dan bergantung pada keluarga maupun lingkungan terdekatnya. Selain itu minimnya lapangan kerja di sektor formal yang mau menerima penyandang difabel juga menjadi alasan sendiri bagi mereka untuk berwirausaha.

\section{Aksesibilitas Permodalan Perbankan Bagi Wirausahawan Difabel}

Hanya sebagian kecil wirausahawan difabel yang mengakses dana permodalan perbankan. Hal ini dikarenakan proses pengurusan persyaratan di bank yang menurut mereka sangat menyulitkan. Pengalaman wirausahawan 
difabel beristeraksi dengan perbankan dalam hal pengajuan pinjaman modal dapat diketahui dari penjelasan Zainudin sebagai berikut:

"Pengalaman dengan BRI di Banguntapan saya itu kalau tanda tangan tidak boleh, hanya boleh pake cap jempol. Pihak BRI kemudian menanyakan kondisi istri saya (apakah normal), lalu saya ditawari pake nama istri saya saja untuk meminjam di Bank Sleman. Saya perah bergurau dengan pegawai bank, "ini kan yang pinjem istri saya, kalau istri saya gak bisa bayar, saya lepas tanggung jawab ya!" "ya gak bisa pak, makanya bapak tanda tangan juga". "Iha katanya saya gak boleh tanda tangan!" "iya pak pake cap jempol aja." mungkin bagi sebagian teman itu tidak marem kalau tidak tanda tangan sendiri. Kalau saya yang penting saya dapat pinjaman meski pake nama istri saya tidak masalah. Yang penting kalau ke bank kita punya sertifikat, BPKB (agunan). Tapi tetap jadi masalah bagi saya karena bunganya masih tinggi hehe..."

Pengalaman serupa terkait interaksi dengan perbankan juga pernah dialami oleh Supriyanto, berikut pernyataannya:

"Saya awal pinjem uang di bank itu pinjem (pakai) nama orang tua saya karena kalau pakai nama saya itu susah karena saya kan buta. selain itu saya gak berani pinjem banyak-banyak, dulu sempet ditolak sama bank karena gak punya jaminan. Jadinya saya agak takut mau masuk bank. Akhirnya saya menjalankan usaha saya. Awalnya Cuma punya satu tempat pijat terus nambah-nambah, sekarang sudah ada di 5 lokasi yang lux saya juga punya yang pake ruang berAC. Sekarang saya sudah berani masuk bank karena saya sudah punya barang. Pinjem pake nama saya sendiri saya juga sudah berani. Bahkan sekarang pihak bank yang datang ke saya nawarin pinjaman. Hahaha... tapi kalau inget yang dulu saya ada sedikit trauma dengan bank makanya di PERTUNI ini saya menginisiasi berdirinya koperasi karena kasian temen-temen netra yang butuh pinjaman dia mau ke mana."

Pengalaman Zainudin dan Supriyanto di atas mencerminkan bahwa layanan perbankan terutama terkait pinjaman modal masih sangat sulit diakses oleh wirausahawan difabel. Hal ini dikarenakan bagi difabel netra persyaratan yang harus dipenuhi untuk dapat mengakses layanan perbankan masih cukup rumit, yaitu tentang adanya syarat pendamping dan agunan yang ditetapkan oleh bank dirasa cukup memberatkan bagi wirausahawan difabel netra. Terbatasnya akses wirausahawan difabel juga dijelaskan oleh Ujang Kamaludin selaku ketua Persatuan Penyandang Disabilitas Indonesia (PPDI) cabang DIY. Ujang menyatakan:

"Problemnya begini, untuk tuna netra misalnya, urusan dengan bank itu kan (tuna netra) harus ada pendamping padahal kan ini urusan pribadi. Belum lagi kalau apa-apa harus ada pendamping itu kan masih harus janjian, ngongkosi (pendamping) nah, ini kan repot. setiap orang kan punya privasi masing-masing. Untuk tuna daksa, yang gak punya tangan itu kan repot mau tanda tangan pake kaki pas di bank itu, kakinya harus naik ke meja kan repot apa ya (pihak bank) menerima (nyaman) dengan kondisi yang seperti itu? Kemudian untuk pelayanan coba lihat saja meja-meja kasir (teller) di bank itu, tinggi-tinggi kan? paling itu $120 \mathrm{~cm}$. Gimana bisa yang pake kursi roda menulis dan yang gak punya tangan tadi? Kemudian tangga, mau masuk bank harus naik tangga ini menyulitkan yang 
pake kursi roda atau krek. Belum lagi kalau masuk ruang ATM dan mengoperasikan mesin ATM. Artinya tidak hanya dari sisi layanan saja dari sisi sarana saja sudah repot. Ini baru mau masuk bank saja sudah susah. Problemnya disitu. Tidak ramah difabel. Padahal kalau mau jujur semua orang itu berpotensi difabel. Begitu, problemnya banyak sekali."

Berdasarkan pernyataan ketua PPDI-DIY di atas memperkuat argumentasi sebelumnya bahwa akses layanan perbankan saat ini masih belum aksesibel bagi para penyandang difabel. Kurangnya aksesibilitas tidak hanya terbatas pada layanannya saja, namun juga pada sarana dan prasarana seperti konsep bangunan dan perlengkapan bank yang belum ramah difabel. Padahal sarana-prasana ini sebagai gerbang awal bagi para penyandang difabel untuk bisa berinteraksi dengan layanan perbankan.

Hal yang sedikit berbeda dialami oleh wirausahawan difabel daksa terkait layanan perbankan. Dari sisi aksesibilitas program layanan, wirausahawan difabel daksa tidak mengalami kesulitan yang berarti seperti halnya wirausahawan difabel netra. Namun, untuk masalah sarana dan prasarana bank yang belum ramah difabel ini juga dipertegas dengan pernyataan Puji Santoso selaku sekretaris Ojek Difa:

"Iya, welcome (pihak perbankan). dalam arti memang kita tetep selektif njih. karena memang selama ini temen-temen difabel sering ternina-bobokan dengan mereka dalam arti sering diberikan bantuan akhirnya tanggungjawabnya kurang. Saya tidak mau itu terjadi di teman-teman ojek Difa. dengan tanggungjawab yang harus mereka tanggung tapi tidak dijalankan, taunya hanya kasihan. Kadang dikasih dana bergulir aja kan kadang macet. makanya fenomena di temen-temen adalah kredit macet sering terjadi. ada teman saya difabel tapi mereka sangat dipercaya sama bank karena tertib mengangsur. sebenarnya kalau mau akses permodalan di bank kan yang penting kita ada kemampuan untuk mengangsur dan ada jaminan. namun memang secara sarana prasarana di bank memang kurang aksesibel. contohnya saja kayak ATM kan gak ada yang ramah difabel. ke kantornya aja juga susah kita."

Selain sarana dan prasarana yang belum ramah difabel, ada hal yang lebih sensitif yang sempat dirasakan oleh para penyandang difabel kaitannya dengan interaksi bersama pihak perbankan. Ada semacam diskriminasi atau resistensi dari pihak bank ketika menghadapi (calon) nasabah difabel. Hal ini dirasakan oleh Ujang sebagai berikut:

"Waktu saya mau buka rekening dan mau bikin ATM itu saya sampe berdebat dengan pihak bank. Katanya gimana nanti mencet PINnya. Saya bilang, sini kalau tidak percaya saya bisa sendiri (pencet PIN dan hafal letak nomornomornya). Meski akhirnya saya boleh pakai ATM, tapi itu pun setelah sampai lama berdebat terus. Dari sini kan dapat dilihat bahwa masih ada resistensi dari pihak bank pada kaum difabel".

Kholid juga merasakan hal yang sama. Ada semacam 'under estimate' dari layanan perbankan yang sempat ia rasakan. Berikut pernyataan Kholid:

"Memang di dalam kehidupan kita itu komplek banget ya. Ndak bisa kita itu dipandang hanya dari sudut a atau b atau c. apalagi kalau kita sudah bicara tentang perekonomian itu mau gak mau yang bersangkutan itu kebanyakan entah 
... kadang ada perlakuan yang berbeda antara yang bukan disabilitas dengan yang disbilitas. Kadang saya itu yo ngelus dodo, lha wong podo-podo bangsa indonesiane kok dibeda-bedakkno to yo..."

Perlakuan yang mengakibatkan para penyandang difabel ini merasa dibedabedakan, sangat mempengaruhi aksesibilitas para penyandang difabel terhadap layanan perbankan. Beberapa permasalahan yang telah disebutkan di atas menjadi faktor bagi para wirausahawan difabel untuk memilih tidak berinteraksi dengan dunia perbankan.

\section{Pandangan Perbankan tentang Akses Permodalan bagi (calon) Nasabah Difabel}

Informasi terkait akses permodalan yang disediakan oleh perbankan peneliti dapatkan dari seseorang praktisi perbankan yang menjabat kepala cabang pembantu Bank Pemerintah Daerah (BPD) DIY. Berikut pernyataan beliau:

"Di instansi kami belum ada produk khusus seperti itu. Untuk permodalan bagi wirausahawan memang kami ada, tetapi yang khusus diperuntukkan bagi wirausahawan difabel, belum ada. Dan dalam waktu dekat belum ada wacana untuk menyiapkan produk khusus layanan perbankan bagi peyandang disabilitas"

Lebih lanjut beliau menjelaskan tentang produk atau layanan bank yang tersedia di BPD DIY:

"Sebetulnya produk kami, baik tabungan maupun pinjaman bisa diakses oleh siapa saja. Namun tentu saja yang memenuhi persyaratan. Nah, untuk calon nasabah difabel netra, tentu harus ada pendamping karena dokumen-dokumen kan harus disetujui lalu ditandatangani ya. Sedangkan untuk menyetujui dokumen tersebut, calon nasabah harus membaca dan memamhami isinya. Itu sebabnya diperlukan pendamping bagi difabel netra saat akan membuka rekening di bank kami."

Jika melihat populasi kaum difabel netra, khususnya yang berwirausaha, yang jumlahnya cukup banyak, apakah tidak ada arah untuk nantinya membuka akses para wirausahawan difabel, berikut jawaban dari beliau:

"Bukan tidak ada ya, tetapi karena beberapa hal, maka kami memang belum bisa menyediakan produk khusus tersebut. Kendalanya, aalah satunya tentang pendamping tadi. Untuk calon nasabah difabel netra, pendamping memiliki kriteria khusus, selain harus dalam KK yang sama juga harus disyahkan secara hukum melalui keputusan pengadilan bahwa seseorang tersebut adalah pendamping bagi calon nasabah. Hal ini untuk menghindari akibat yang tidak diinginkan di kemudian hari. Nah, untuk mendapatkan pengesahan dari pengadilan tersebut biasanya membutuhkan waktu yang lama, bahkan bisa jadi berbulan-bulan bahkan sampai 1 tahun. Tentu saja dari sisi calon nasabah yang bersangkutan ini akan merepotkan dan bagi kami juga menjadi tidak efektif dengan proses yang begitu lama. Kendala lainnya terkait dokumen-dokumen yang harus dilengkapi, dibaca, disetujui dan ditandatangani oleh calon nasabah tersebut. Di sistem kami saat ini, kami hanya memiliki dokumen yang harus dibaca dengan kondisi fisik normal. Artinya kami belum memiliki dokumen yang dicetak dalam huruf Braille, yang tentu memudahkan bagi calon nasabah difabel 
netra dalam memahami isinya. Karena teknologi yang kami miliki saat ini belum memungkinkan untuk menyediakan dokumen dalam huruf Braille tersebut. Ataupun mungkin dalam bentuk lain yang lebih mudah untuk diakses oleh calon nasabah difabel netra. Hal ini karena teknologi yang mendukung ke arah itu masih sangat mahal biayanya."

Berdasarkan pernyataan praktiksi BPD DIY tersebut dapat diketahui bahwa belum ada produk layanan khusus yang ditujukan bagi nasabah difabel. Adanya persyaratan perbankan yang mengatur (calon) nasabah difabel netra justru mempersulit para penyandang difabel netra untuk bisa mengakses layanan perbankan. Pernyataan serupa terkait akses permodalan perbankan bagi wirausahawan difabel juga diberikan oleh praktisi Bank Nasional Indonesia (BNI) 46 cabang DIY. Beliau menyatakan:

"Dasar pemberian kredit (permodalan) bagi nasabah ada persyaratan yang mengaturnya. Persyaratan tersebut harus diverifikasi. Harapan kami dalam proses pengajuan kredit terutama oleh penyandang tuna netra itu harus didampingi oleh keluarga terdekat. Saat ini belum ada regulasi perbankan yang mengatur secara spesifik tentang penyandang difabel. Walaupun ada Undangundang yang secara umum menyatakan bahwa penyandang difabel memiliki kesempatan yang sama."

Dari dua pernyataan praktisi perbankan tersebut dapat disimpulkan bahwa belum adanya regulasi pemerintah yang mengatur tentang layanan perbankan bagi penyandang difabel cukup membatasi gerak perbankan ketika hendak melayani (calon) nasabah difabel. Pihak perbankan dalam hal ini hanya menjalankan peraturan yang sudah ada. Perlu adanya kajian yang intens dan mendalam terkait regulasi perbankan bagi penyandang difabel untuk membuka peluang yang sebesar-besarnya dan layanan ramah (aksesibel) bagi para penyandang difabel.

\section{KESIMPULAN}

Berdasarkan hasil penelitian di atas dapat ditarik kesimpulan bahwa sebagian besar wirausahawan difabel netra menjalankan usaha di bidang jasa pijat (massage). Beberapa wirausahawan difabel netra juga berprofesi sebagai pedagang dan sebagian kecil berprofesi sebagai guru. Wirausahawan difabel daksa yang tergabung di Ojek Difa DIY berprofesi sebagai tukang ojek yang menjalankan armada motor yang telah dimodifikasi dan disesuaikan dengan kondisi para difabel daksa. Sebagian wirausahawan difabel daksa berprofesi sebagai pedagang. Sebagian kecil wirausahawan difabel netra pernah berinteraksi dengan pihak perbankan, selebihnya lebih memilih berinteraksi dengan lembaga keuangan lainnya misalnya koperasi dan BMT.

Wirausahawan Difabel lebih memilih mengakses layanan permodalan di koperasi atau BMT karena pelayanan perbankan dirasa cukup rumit atau bersifat tidak akses bagi wirausahawan difabel netra. Sebaliknya, wirausahawan difabel daksa selama ini sudah sering berinteraksai dengan perbankan dan tidak ada permasalah yang berarti dalam proses peminjaman modal bank. Namun demikian, baik wirausahawan difabel netra maupun daksa berharap adanya peningkatan layanan bagi para wirausahawan difabel utamanya dalam hal fasilitas sarana dan 
prasarana (konsep bangunan) serta produk layanan perbankan yang lebih ramah difabel.

Pihak perbankan belum memiliki program layanan khusus untuk nasabah penyandang difabel. Hal ini dikarenakan belum adanya peraturan khusus dari pemerintah yang mengatur tentang akses permodalan perbankan bagi wirausahawan difabel. Adanya peraturan tentang akses layanan perbankan yang mengatur nasabah difabel netra, itu pun dirasa masih menghambat aksesibilitas permodalan perbankan bagi wirausahawan difabel, khususnya bagi wirausahawan difabel netra.

Adapun saran atas penelitian ini adalah sebagai berikut: (1) Bagi Wirausahan Difabel diharapkan hasil penelitian ini dapat digunakan sebagai bahan acuan serta masukan dalam mekakukan upaya-upaya yang lebih intens terhadap pihak-pihak terkait (perbankan, otoritas jasa keuangan, pemerinta) untuk membuka akses permodalan perbankan yang luas bagi wirasusahawan difabel, khususnya wirausahawan difabel netra; (2) Bagi Perbankan diharapkan untuk mempertimbangkan produk khusus yang dapat mengakomodir kebutuhan permodalan bagi wirausahawan difabel dalam rangka meningkatkan kemandirian ekonomi wirausahawan difabel untuk mewujudkan ekonomi inklusi. Perbankan baiknya juga memperhatikan sarana dan prasarananya (konsep bangungan) agar lebih ramah difabel; (3) Bagi Otoritas Jasa Keuangan (OJK) diharapkan untuk merancang kebijakan permodalan perbankan yang lebih akomodatif terhadap wirausahawan difabel guna mewujudkan ekonomi inklusi dan (4) Bagi Peneliti Berikutnya, penelitian ini hanya menggunakan metode kualititatif, diharapkan penelitian selanjutnya dapat meneliti dengan metode kuantitatif yang mampu memperediksi berapa banyak partisipasi dan besaran nilai permodalan yang dapat diakses oleh wirausahawan difabel.

\section{DAFTAR PUSTAKA}

Anggraini, Dewi dan Syarif Hakim Nasution. 2013. Peranan Kredit Usaha Rakyat (KUR) Bagi Pengembangan UMKM di Kota Medan (Studi Kasus Bank BRI). Jurnal Ekonomi dan Keuangan Vol. 1 No. 3, Februari 2013.

Damsar. 2006. Sosiologi Ekonomi. Jakarta: PT Raja Grafindo Persada.

Denzin, Norman k dan Yvonna S Lincoln (Eds.). 2002. Handbook Of Qualitative Research, Edisi Bahasa Indonesia. Yogyakarta: Pustaka Belajar.

Efendi, M. 2009. Pengantar Psikopedagogik Anak Berkelainan. Jakarta : Bumi Aksara.

Hafni, Diska Arliena. 2017. Studi Fenomenologi: Praktik dan Makna Akuntansi bagi Wirausahawan Difabel Netra pada Usaha Mikro di Daerah Istimewa Yogyakarta. KOMPARTEMEN Jurnal Ilmiah Akuntansi Vo. XV No.2 Hlm. 82-101, September 2017 e-ISSN: 2579-8928 p-ISSN:1693-1084.

Hisbullah, Jousairi. 2006. Social Capital. Jakarta: MR- Unated Pers.

Hutomo, Mardi Yatmo. (2000). Pemberdayaan Masyarakat dalam Bidang Ekonomi: Tinjauan Teoritik dan Implementasi, Working Paper.

Karsidi, Ravik. 2007. Pemberdayaan Masyarakat untuk Usaha Kecil dan Mikro (Pengalaman Empiris di Wilayah Surakarta Jawa Tengah). Jurnal Penyuluhan Vol. 3 No.2, September 2007 ISSN1858-2664. 
Moleong, J. Lexy. 2002. Metodologi Penelitian Kualitatif. Bandung: PT Remaja Rosdakarya.

Mujaddid. 2014. Kesehatan anak dengan disabilitas. Buletin Jendela Data dan Informasi Kesehatan, Semester II tahun 2014. Hal 25-30.

Rostiana \& Damayanti, S. 2003. Dinamika emosi penyandang tunadaksa pasca kecelakaan.Jurnal Psikologi Arkhe, 1, 15-28.

Sarinem. 2010. Pelayanan Rehabilitasi Sosial Penyandang Cacat Tubuh di UPT Rehabilitasi Sosial Cacat Tubuh Pasuruan Jawa Timur. Meida Info Letkos, 34, $391-406$.

Sugiyono. (2007). Memahami Penelitian Kualitatif. Bandung: Penerbit Alfabeta.

Sukoharsono, E.G. (tanpa tahun). Alternatif Riset Kualitatif Sains Akuntansi: Biografi, Phenomenologi, Grounded Theory, Critical Ethnografi, dan Case Study dalam Analisis Makro dan Mikro: Jembatan Kebijakan Ekonomi Indonesia, hal 230-245. Ashar, K. Irianto, G, Suryadi, N. (2006). BPFE Universitas Brawijaya, Malang.

Surwanti, Arni. (2014). Model Pemberdayaan Ekonomi Penyandang Disabilitas di Indonesia. Jurnal Manajemen dan Bisnis Vol. 5 No. 1 Maret 2014.

Winasti, Milu. 2012. Motivasi Bewirausaha Pada Penyandang Disabilitas Fisik. Jurnal EMPATHY Vol.I No.1 Desember 2012.

www.depkes.go.id diakses pada 17 Oktober 2016

http://temuinklusi.sigab.or.id/2016/unduh-2/ diakses pada 20 Oktober 2016

Undang-undang Nomor 19 Tahun 2011 tentang CPRD 